\title{
PENGARUH MILLING TERHADAP KARAKTERISTIK MOLECULARLY IMPRINTED POLYMER KARBARIL $\left(\mathrm{C}_{12} \mathrm{H}_{11} \mathrm{NO}_{2}\right)$
}

\author{
Suci Aprilia ${ }^{1}$, Susilowati ${ }^{2}$, Erry Koriyanti ${ }^{3}$, Fiber Monado $^{3}$, Idha Royani ${ }^{3 *}$ \\ ${ }^{1}$ Prodi Magister Fisika, Fakultas Matematika dan Ilmu Pengetahuan Alam, Universitas Sriwijaya, Palembang, 30137, Indonesia \\ ${ }^{2}$ Prodi Fisika, Fakultas Matematika dan Ilmu Pengetahuan Alam, Universitas Sriwijaya, Indralaya, 30662, Indonesia \\ ${ }^{3}$ Jurusan Fisika, Fakultas Matematika dan Ilmu Pengetahuan Alam, Universitas Sriwijaya, Indralaya, 30662, Indonesia \\ *e-mail: idharoyani@unsri.ac.id
}

\begin{abstract}
ABSTRAK
Molecularly Imprinted Polymer (MIP) telah disintesis dengan karbaril yang digunakan sebagai template dan membentuk ikatan kompleks dengan Methacrylic Acid (MAA) melalui ikatan hidrogen, diikuti oleh proses cross-linking menggunakan Ethylene Glycol Dimethacrylate (EGDMA) cross-linker. Proses polimerisasi dimulai dengan dekomposisi termal Benzoil Peroksida (BPO) sebagai inisiator. Sebagai polimer kontrol Non Imprinted Polymer (NIP) juga telah disintesis menggunakan prosedur serupa tanpa menggunakan karbaril. Pada penelitian ini digunakan dua variasi bahan aktif karbaril yaitu karbaril yang tidak di milling dan karbaril telah di milling menggunakan alat High Energy Milling (HEM). Studi FTIR dilakukan untuk menyelidiki keberadaan karbaril dalam polimer, MIP, dan NIP. Spektrum menunjukkan bahwa konsentrasi senyawa karbaril berkurang setelah proses ekstraksi. Hasil ini juga dikonfirmasi oleh kenaikan nilai persentase transmitansi pada MIP terutama MIP nano karbaril. Hal ini didukung dari hasil X-RD yang menunjukkan terjadi penurunan ukuran kristal pada MIP nano karbaril yaitu dari 9,16 ̊ sedangkan pada MIP karbaril sebesar 10,07 .
\end{abstract}

Kata Kunci: MIP; Karbaril; HEM; Milling; Cooling Heating.

\section{ABSTRACT}

[Title: The Effect of Milling on Molecularly Imprinted Polymer Carbaryl ( $\left.\mathrm{C}_{12} \mathrm{H}_{11} \mathrm{NO}_{2}\right)$ Characteristics] Molecularly Imprinted Polymer (MIP) has been synthesized with carbaryl used as a template and forms complex bonds with Methacrylic Acid (MAA) through hydrogen bonds, followed by a cross-linking process using Ethylene Glycol Dimethacrylate (EGDMA) cross-linkers. The polymerization process begins with the thermal decomposition of Benzoyl Peroxide (BPO) as an initiator. Non-Imprinted Polymer (NIP) as a control polymer has also been synthesized using a similar procedure without using carbaryl templates. In this study, two variations of carbaryl are used, which are not milled carbamates, and carbaryl has been milled using High Energy Milling (HEM). The FTIR study was carried out to investigate the presence of carbaryl in polymers, MIP, and NIP. The spectrum shows that the concentration of carbaryl compound decreases after the extraction process. This result was also confirmed by the increase in the value of the percentage of transmittance in the MIP, especially the nano carbaryl MIP. This result is supported by the X-RD results, which showed a decrease in the size of the crystals in the carbaryl MIP from $10.07 \AA$ while the nano carbaryl MIP was $9.16 \AA$.

Keywords: MIP; Carbaryl; HEM; Millin; Cooling Heating.

\section{PENDAHULUAN}

Molecularly Imprinted Polymer (MIP) atau polimer tercetak secara molekular merupakan salah satu metode pemisahan yang telah dikembangkan sejak tahun 1970 (Qobliyah, dkk. 2018). MIP merupakan polimer selektif tingkat tinggi yang memiliki sisi aktif pengenal dan mampu berikatan ulang secara spesifik dengan analit atau senyawa lainnya yang berhubungan (Dwi, R, C. 2018). MIP mempunyai banyak keuntungan, antara lain stabilitas kimia yang tinggi, dapat digunakan lebih dari satu kali pakai, kestabilan mekanik dan kimia yang tinggi, sintesis atau pembuatannya relatif mudah, dan dapat diproduksi ulang dengan biaya yang terjangkau (Ningtias, dkk. 2018 ; Dwi, R, C. 2018). Sebagai adsorben yang efisien, MIP dapat digunakan sebagai adsorben untuk mendeteksi pestisida dalam air dan MIP dapat menjadi sebuah metode untuk menyusun rongga dalam polimer berdasarkan 'bentuk' target (Royani, dkk. 2019), seperti misalnya pestisida karbaril (Juyhok, dkk. 2018 ; Diaz, dkk. 2018 ; Kecili, dkk. 2018).

Karbaril (1-naphthyl methyl carbamate) adalah salah satu pestisida yang paling banyak digunakan dalam pertanian. Program Survei Geologi AS yaitu National Water Quality Assessment (NAWQA) 
melaporkan karbaril sebagai pestisida kedua yang paling sering ditemukan dalam air. Residu pestisida karbaril adalah masalah serius dalam industri makanan dan pengolahan untuk produk pertanian dan menyebabkan masalah keamanan pangan di banyak tempat, sehingga penelitian tentang MIP untuk mendeteksi toksisitas karbaril telah menjadi bidang penting dalam lingkungan (Juyhok, dkk. 2018).

Teknologi MIP didasarkan pada pembentukan kompleks antara template dan monomer fungsional dalam pelarut tertentu, kemudian dipolimerisasi pada suhu tertentu dengan penambahan cross-linker sehingga terbentuk polimer tiga dimensi (Ningtias, dkk. 2018). Proses polimerisasi memegang kunci penting dalam memperoleh MIP dengan kapasitas pengikatan yang baik (Nurhayati, dkk. 2016). Salah satu metode yang bisa digunakan dalam pembuatan MIP adalah metode cooling-heating yaitu metode pendinginan dan pemanasan pada proses polimerisasi. Waktu yang dihasilkan dari metode cooling-heating lebih efisien dari metode Water Bath (Long, dkk. 2019 ; Koriyanti, dkk. 2020).

Pada penelitian ini, digunakan dua variasi bahan aktif karbaril yaitu karbaril yang tidak di milling dan karbaril telah di milling menggunakan alat High Energy Milling (HEM). HEM berfungsi untuk mereduksi ukuran butiran karbaril ke dalam dimensi nano (Firmansari, dkk. 2016). Material yang direduksi ukurannya menjadi nano memiliki sifat kimia dan fisika yang lebih unggul dari material ukuran besar (bulk) (Abdullah, M. 2008). Tujuan utama penelitian ini adalah untuk mengetahui pengaruh milling terhadap karakterisasi dari MIP karbaril yang dihasilkan. Adapun alat karakterisasi yang digunakan dalam penelitian ini adalah Fourier Transform Infra Red (FTIR) Nicolet is 10 FTIR Spectrometer dan $X-R A Y$ Diffraction (XRD) Rigaku Miniflex 600.

\section{METODE}

Bahan aktif karbaril (0,028 gr), larutan MAA $(0,44 \mathrm{~mL})$, larutan EDMA $(1,9 \mathrm{~mL})$, serbuk BPO $(0,03$ gr) dibeli dari Sigma-Aldrich. Acetonitril, metanol, asam asetat, dan aquabidest dibeli dari Merck. Semua bahan kimia dan reagen lainnya memiliki kemurnian tertinggi, sehingga dapat digunakan tanpa pemurnian lebih lanjut.

Pada proses sintesis MIP serbuk nano karbaril, larutan MAA, larutan EDMA, serbuk BPO, dimasukkan kedalam pelarut acetonitril. Larutan diaduk menggunakan magnetic stirrer selama 15 menit. Selanjutnya larutan didinginkan di dalam lemari pendingin pada suhu $-5^{\circ} \mathrm{C}$ ditahan selama 1 jam. Kemudian dipanaskan menggunakan furnace pada suhu $75^{\circ} \mathrm{C}$ ditahan selama 3 jam, $80^{\circ} \mathrm{C}$ ditahan selama 2 jam, dan $85^{\circ} \mathrm{C}$ ditahan selama 1 jam. Polimer padatan yang dihasilkan kemudian digerus menggunakan alu mortar sampai membentuk serbuk. Langkah yang sama pun juga digunakan dalam pembuatan MIP karbaril yang telah di milling dan NIP, hanya saja NIP di sintesis tanpa menggunakan bahan aktif karbaril. Selanjutnya MIP karbaril, MIP nano karbaril dan NIP dikarakterisasi menggunakan FTIR untuk melihat apakah polimer yang dihasilkan sudah sesuai dengan harapan dan X-RD untuk melihat ukuran kristal dari polimer.

\section{HASIL DAN PEMBAHASAN}

Pada penelitian ini telah dilakukan proses polimerisasi MIP berbahan aktif karbaril sebagai template dengan metode cooling - heating. Cooling bertujuan untuk memperlambat reaksi antar senyawa yang ada di dalam larutan dengan oksigen yang dapat mempengaruhi proses polimerisasi. Sedangkan pemanasan secara bertahap pada proses heating bertujuan untuk membantu mempercepat pembentukan polimer padatan (Koriyanti, dkk. 2020).

Proses sintesis MIP ini menggunakan metode polimerisasi dan ekstraksi. Parameter yang digunakan sebagai penentu keberhasilan proses polimerisasi MIP salah satunya adalah monomer. Setiap monomer dapat menghasilkan rongga yang spesifik terhadap molekul templatenya. Gugus fungsi monomer harus sesuai dengan gugus fungsi yang terdapat pada molekul template, agar cetakan mudah terbentuk dan juga pada proses ekstraksi MIP sangat menentukan jumlah karbaril yang terbuang (Dwi, R, C. 2018).

Polimer yang diperoleh baik sebelum dan sesudah proses ekstraksi dikarakterisasi dan dianalisis menggunakan FTIR. Spektra infra-red dari uji FTIR pada dari polimer karbaril, polimer nano karbaril, MIP karbaril, MIP nano karbaril dan NIP direkam dalam range gugus fungsi pada permukaan adsorben berkisar antara 400-4000 $\mathrm{cm}^{-1}$. Adapun spektrum IR yang dihasilkan disajikan dalam Gambar 1 dan 2.

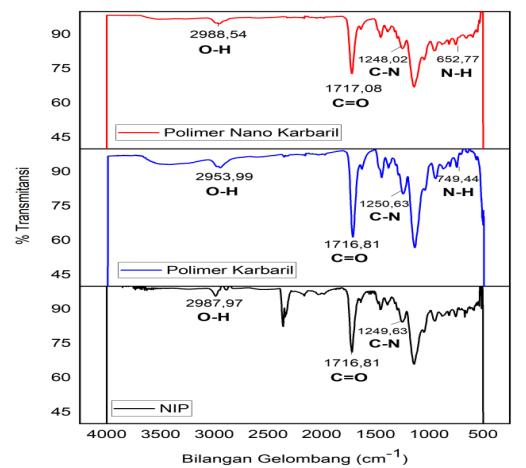

Gambar 1. Grafik FTIR polimer nano karbaril, polimer karbaril, dan NIP. 
Gambar 1 menjelaskan adanya spektrum pada rentang bilangan gelombang 2500-3300 $\mathrm{cm}^{-1}$ yang menunjukkan adanya gugus fungsi $\mathrm{O}-\mathrm{H}$ stretch dari gugus fungsi karboksilat sebagai penciri monomer MAA (Yanti, dkk. 2016). Pada bilangan gelombang $1690-1760 \mathrm{~cm}^{-1}$ menunjukkan adanya gugus karbonil $\mathrm{C}=\mathrm{O}$ yang kuat karena adanya interaksi antara template dan monomer. Selain itu pada bilangan gelombang 1000-1300 $\mathrm{cm}^{-1}$ merupakan gugus fungsi C-O banding, menunjukkan keberadaan dari EDMA (Yanti, dkk. 2016). Bilangan gelombang 650-750 cm ${ }^{1}$ merupakan gugus fungsi dari N-H (amina sekunder) yang menjadi ciri khas gugus fungsi karbaril.

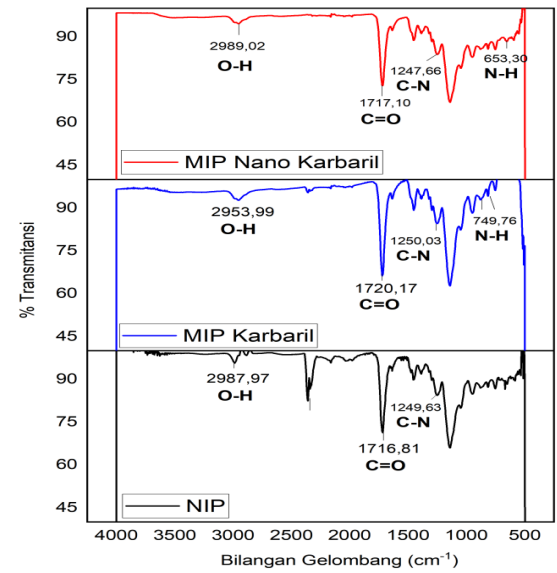

Gambar 2. Grafik FTIR MIP nano karbaril, MIP karbaril, dan NIP.

Gambar 2 menunjukkan spektra IR dari MIP nano karbaril, MIP karbaril dan NIP. Jika dibandingkan MIP karbaril, maka MIP nano karbaril memiliki nilai transmitansi yang lebih besar. Data ini menyampaikan informasi bahwa karbaril dalam bentuk nano lebih mudah terekstraksi dibanding ukuran yang lebih besar (bulk). Hal ini sejalan jika ukuran partikel diperkecil ke skala nano meter, reaktivitas material tersebut berubah secara drastis, semakin kecil ukuran partikel maka semakin reaktif partikel tersebut terhadap reaksi kimia. Sehingga dapat dijelaskan bahwa karbaril yang berukuran nano dapat mempermudah pelepasan karbaril pada saat proses ekstraksi (Abdullah, M. 2008).

Keberhasilan proses ini tidak hanya bergantung pada proses sintesis namun juga bergantung pada ukuran partikel template (Maimuna, dkk. 2020). Oleh karena itu untuk melihat lebih detail ukuran kristal yang terbentuk pada MIP karbaril dan MIP nano karbaril, maka dilakukan uji karakterisasi X-RD. Adapun grafik X-RD dari masing-masing MIP disajikan pada Gambar 3.

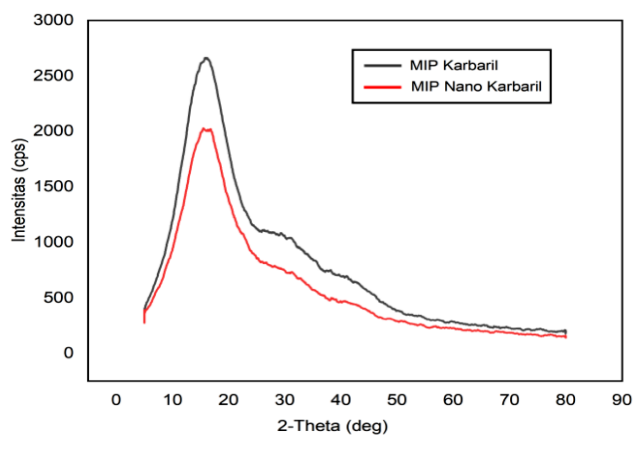

Gambar 3. Grafik X-RD MIP nano karbaril dan MIP karbaril.

Pada Gambar 3 menunjukkan bahwa terjadi penurunan intensitas pada MIP nano karbaril. Dapat dilihat intensitas MIP karbaril lebih besar jika dibandingkan dengan MIP nano karbaril. Hal ini menunjukkan pada MIP karbaril terdapat lebih banyak atom-atom yang mendifraksikan sinar-X (Nurhayati, dkk. 2016). Sedangkan pada MIP nano karbaril terdapat nilai intensitas yang semakin berkurang dan puncak difraksi yang semakin melebar.

Untuk mengetahui ukuran kristal pada MIP karbaril dan MIP nano karbaril dapat ditentukan dengan menggunakan persamaan Scherrer (Koriyanti, dkk. 2020).

$$
D=\frac{k \lambda}{B \cos \theta}
$$

$D$ adalah diameter kristal, $\lambda$ adalah panjang gelombang sinar-X, B adalah Full Width at Half Maximum $(F W H M)$ yaitu lebar setengah puncak maksimum yang dihitung dalam radian, $\theta$ adalah sudut difraksi dan $k$ adalah konstanta material yang nilainya 0,9 . Ukuran kristal yang dihasilkan dapat dilihat pada Tabel 2 .

Tabel 2. Hasil X-RD MIP nano karbaril dan MIP karbaril

\begin{tabular}{clcc}
\hline No & Peak List & $\begin{array}{c}\text { MIP } \\
\text { Karbaril }\end{array}$ & $\begin{array}{c}\text { MIP nano } \\
\text { karbaril }\end{array}$ \\
\hline 1 & $2 \theta(\operatorname{deg})$ & 15,70 & 16,25 \\
3 & d $(\AA)$ & 5,64 & 5,45 \\
4 & FWHM (deg) & 7,97 & 8.76 \\
5 & D $(\AA)$ & 10,07 & 9,16 \\
\hline
\end{tabular}

Pada Tabel 2 menginformasikan bahwa MIP nano karbaril mempunyai nilai FWHM yang lebih besar dari MIP karbaril. Semakin kecil nilai FWHM maka semakin luas bidang kristal, sebaliknya semakin besar nilai FWHM maka semakin sempit bidang kristal (Maimuna, dkk. 2020). Sempitnya bidang kristal didukung oleh jarak antar atom (d) 
penyusunnya yang semakin dekat. Jarak antar atom MIP nano karbaril lebih kecil jika dibandingkan dengan MIP karbaril. Sehingga mengakibatkan daerah bidang pantul dari sinar-X lebih terbatas dan membuat nilai intensitas pada MIP nano karbaril lebih rendah. Kemudian ukuran kristal yang terbentuk dari MIP berbahan aktif nano karbaril lebih kecil jika dibandingkan dengan MIP karbaril.

\section{KESIMPULAN}

Berdasarkan hasil karakterisasi FTIR gugus fungsi N-H sebagai penciri karbaril mengalami penurunan konsentrasi yang cukup signifikan. Terutama pada MIP nano karbaril. Hal ini mengindikasikan bahwa polimer yang dihasilkan memiliki cetakan karbaril yang banyak. Analisis XRD menunjukkan bahwa ukuran kristal MIP nano karbaril lebih kecil yaitu 9,16 ̊̊, jika dibandingkan ukuran kristal MIP karbaril yaitu 10,07 A.

\section{UCAPAN TERIMAKASIH}

Ucapan terima kasih disampaikan kepada Lembaga Penelitian Universitas Sriwijaya atas bantuan dana melalui riset Hibah Unggulan Kompetitif.

\section{DAFTAR PUSTAKA}

Abdullah, M. 2008. Pengantar Nanosains. Bandung: Intitut Teknologi Bandung.

Diaz, D, L. Aguilar, M. Perez, R. Hernandez, O. Barriga, G. Esquivel, D. Ramirez, B. 2018. Synthesis and Evaluation of a Molecularly Imprinted Polymer for the Determination of Metronidazole in Water Samples. Bulletin of Environmental Contamination and Toxicology. March 2018, Volume 100, Issue 3, pp 395-401.

Dwi, R, Chrisnandari. 2018. Sintesis dan Karakterisasi Molecularly Imprinted Polymer Untuk Kloramfenikol Menggunakan Polimerisasi Fasa Ruah. Surabaya: Akademi Farmasi surabaya.

Firmansari, V. Ratnawulan, Ramli, Fauzi, A. 2016. Pengaruh Waktu Milling Terhadap Ukuran Butir Forsterite $\left(\mathrm{Mg}_{2} \mathrm{SiO}_{4}\right)$ Dari Batuan Dunit Di Daerah Jorong Tongar Nagari Aur Kuning, Kabupaten Pasaman Barat. Padang: Universitas Negeri Padang.

Juyhok, S. Pang, C. Dong, H. Jang, P. U, J. Ri, K. Yun, C. 2018. Adsorption Of 1-Naphthyl Methyl Carbamate in Water By Utilizing a Surface Molecularly Imprinted Polymer. Pyongyang: University of Science.

R. Dungani, P. Aditiawati, S. Aprilia, k. Yuniarti, T. Karliati, I. Suwandhi, I. Sumardi. 2018.
Kecili, R. Mustansar, H. Hussain. 2018. Review Article Recent Progress of Imprinted Nanomaterials in Analytical Chemistry. Hindawi. International Journal of Analytical Chemistry. Volume 2018, Article ID 8503853, 18 pages.

Koriyanti, E. Saleh, K. Monado, F. Syawali, F. Royani, I. 2020. On The Effect Of Ethanol Solution On Melamine Template Removal Process. Journal Of Chemical Technology And Metallurgy, 55, 1, 2020, 34-39.

Long, Z. Shen, S. Lu, Y. Lan, W. Chen, J. Qiu, H. 2019. Monodisperse Core - Shell - Structured $\mathrm{SiO}_{2} @ \mathrm{Gd}_{2} \mathrm{O}_{3}: \mathrm{Eu}^{3+} @ \mathrm{SiO}_{2} @$ MIP Nanospheres for Specific Identification and Fluorescent Determination of Carbaryl in Green Tea. Analytical and Bioanalytical Chemistry. July 2019, Volume 411, Issue 18, pp 4221-4229.

Maimuna, Monado, F. Royani, I. 2020. Studi Awal Pengaruh Kloroform Sebagai Pelarut Pada Proses Ekstraksi Moleculary Imprinted Polymer. Semarang: Unuversitas Negeri Semarang.

Ningtias, T, D, Utari. Halimah, E. 2018. Review: Penggunaan Monomer Asam Itakonat Pada Molecularly Imprinted Polymer (MIP). Bandung: Universitas Padjajaran.

Nurhayati, T. Yanti. Royani, I. Widayani. Khairurrijal. 2016. Synthesis and Study of Guest Rebinding of MIP Based on MAA Prepared using Theophylline Template. Journal of Physics: Conference Series.

Qobliyah, A, Afgani. Pramita, D, Destiani. 2018. Review artikel: Pengaruh Polaritas Porogen Pada Sintesis Moleculary Imprinted Polymer (MIP). Bandung: Universitas Padjajaran.

Royani, I. Assaidah. Widayani. Abdullah, M. Khairurrijal. 2019. The Effect Of Atrazine Concentration On Galvanic Cell Potential Based On Molecularly Imprinted Polymers (MIPS) And Aluminium As Contact Electrode. Journal of Physics: Conference Series.

Sulistyani, M. Huda,N. 2017. Optimasi Pengukuran Spektrum Vibrasi Sampel Protein Menggunakan Spektrofotometer Fourier Transform Infrared (FT-IR). Semarang: Universitas Negeri Semarang.

Yanti. Nurhayati, T. Royani, I. Widayani. Khairurrijal. 2016. Synthesis and Characterization of MAA-Based MolecularlyImprinted Polymer (MIP) with D-Glucose Template. Journal of Physics: Conference Series. 
Biomaterial from oil palm waste: properties, characterization and applications. IntechOpen. Chapter 3.

R.D.rey, Rodriquez, L. Berto. 2019. Characterization of new sustainable acoustic solution in a reduced sized transmission chamber. Buildings, 9.

S. Shinoj, R.Visvanathan, S. Panigrahi, M. Kochubabu. 2011. Oil palm fiber (OPF) and its composites: A review. Industrial Crops and Products. 33, 7-22.

T.Rihayat, dkk. 2017. Composite material making from empty fruit bunches of palm oil (EFB) and Ijuk (Arengapinnata) using plastic bottle waste as adhesives. IOP Conf. Series. Materials Science and Engineering 334.

X. Sagartzazu · L. Hervella-Nieto · J.M. Pagalday. 2008. Review in sound absorbing materials. Arch Comput Methods Eng 15. 311-342. 